\title{
Obesity in the Balinese is associated with FTO rs9939609 and rs1421085 single nucleotide polymorphisms
}

Lidwina Priliani ${ }^{1}$, Sukma Oktavianthi ${ }^{1}$, Ria Hasnita ${ }^{2,3}$, Hazrina T. Nussa ${ }^{4}$, Rut C Inggriani ${ }^{5}$, Clarissa A Febinia ${ }^{1}$ Anom Bowolaksono $^{4}$, Rini Puspitaningrum ${ }^{2}$, Rully A Nugroho ${ }^{5}$, Ketut Suastika ${ }^{6}$, Safarina G. Malik ${ }^{\text {Corresp. } 1}$

${ }^{1}$ Eijkman Institute for Molecular Biology, Jakarta, Indonesia

2 Faculty of Mathematics and Natural Sciences, Universitas Negeri Jakarta, Jakarta, Indonesia

3 Department of Surgery, Faculty of Medicine, Universitas Indonesia, Jakarta, Indonesia

4 Department of Biology, Faculty of Mathematics and Natural Sciences, Universitas Indonesia, Depok, Indonesia

5 Faculty of Biology, Satya Wacana Christian University, Salatiga, Indonesia

${ }^{6}$ Division of Endocrinology and Metabolism, Department of Internal Medicine, Faculty of Medicine, Universitas Udayana, Denpasar, Indonesia

Corresponding Author: Safarina G. Malik

Email address: ina@eijkman.go.id

Obesity prevalence is increasing worldwide, including in the Bali Province, Indonesia, a popular tourism destination area. The common single nucleotide polymorphisms (SNPs) rs9939609 and rs1421085 of the fat mass and obesity-associated (FTO) gene have been repeatedly reported as one of the important obesity genetic risk factors. We examined the associations of FTO rs9939609 and rs1421085 SNPs with obesity in the 612 unrelated Balinese subjects living in urban and rural areas. Linear and logistic regression analyses with adjustment for age and gender were employed to investigate the association between FTO genotypes, haplotypes and obesity parameters. We found that the FTO SNPS

genotypes increased BMI by $1.25 \mathrm{~kg} / \mathrm{m}^{2}$ ( $p=0.012$ ) for rs9939609 AA and $1.12 \mathrm{~kg} / \mathrm{m}^{2}$ ( $p=$ 0.022 ) for rs $1421085 \mathrm{CC}$, particularly in females and in rural population. Subjects carrying these genotypes also showed a tendency to maintain high BMI, regardless of their age. Our result showed that the FTO rs9939609 and rs1421085 risk alleles were associated with increased BMI and obesity in the Balinese. 
1 Obesity in the Balinese is associated with FTO rs9939609 and rs1421085 single nucleotide 2 polymorphisms

3

4 Lidwina Priliani ${ }^{1}$, Sukma Oktavianthi ${ }^{1}$, Ria Hasnita ${ }^{1,2,3 *}$, Hazrina T. Nussa ${ }^{1,4 *}$, Rut C. 5 Inggriani ${ }^{1,5 *}$, Clarissa A. Febinia ${ }^{1}$, Anom Bowolaksono ${ }^{4}$, Rini Puspitaningrum², Rully A. 6 Nugroho $^{5}$, Ketut Suastika ${ }^{6}$, Safarina G. Malik ${ }^{1 * *}$

7

$8{ }^{1}$ Eijkman Institute for Molecular Biology, Jakarta 10430, Indonesia

92 Faculty of Mathematics and Natural Sciences, Universitas Negeri Jakarta, Jakarta 13220, 10 Indonesia

$11{ }^{3}$ Department of Surgery, Faculty of Medicine, Universitas Indonesia, Jakarta 10430, Indonesia

$12{ }^{4}$ Department of Biology, Faculty of Mathematics and Natural Sciences, Universitas Indonesia, 13 Depok, West Java 16424, Indonesia

145 Faculty of Biology, Satya Wacana Christian University, Salatiga, Central Java 50711, 15 Indonesia

$16{ }^{6}$ Division of Endocrinology and Metabolism, Department of Internal Medicine, Faculty of 17 Medicine, Universitas Udayana, Denpasar, Bali 80232, Indonesia

$18 *$ These authors contribute equally

$19 * *$ Corresponding Author:

20 Safarina G. Malik

21 Jalan Diponegoro no. 69, Jakarta Pusat, 10430, Indonesia. Email address: ina@eijkman.go.id

22 
24 Abstract

25 Obesity prevalence is increasing worldwide, including in the Bali Province, Indonesia, a popular tourism destination area. The common single nucleotide polymorphisms (SNPs) rs9939609 and

27 rs 1421085 of the fat mass and obesity-associated (FTO) gene have been repeatedly reported as one of the important obesity genetic risk factors. We examined the associations of FTO rs9939609 and rs1421085 SNPs with obesity in the 612 unrelated Balinese subjects living in urban and rural areas. Linear and logistic regression analyses with adjustment for age and gender were employed to investigate the association between FTO genotypes, haplotypes and obesity parameters. The minor allele frequency (MAF) for rs9939609 and rs1421085 were rather high, 0.42 and 0.41 , respectively. We found that the FTO SNPs genotypes increased BMI by 1.25 $\mathrm{kg} / \mathrm{m}^{2}(p=0.012)$ for rs9939609 AA and $1.12 \mathrm{~kg} / \mathrm{m}^{2}(p=0.022)$ for rs1421085 CC, particularly in females and in rural population. Subjects carrying these genotypes also showed a tendency to maintain high BMI, regardless of their age. Our result showed that the FTO rs9939609 and rs 1421085 risk alleles were associated with increased BMI and obesity in the Balinese.

Keywords

Obesity, Balinese, BMI, SNPs, FTO, rs9939609, rs1421085 


\section{Introduction}

48 Rapid transition in lifestyle and diet towards excessive consumption of energy-dense food and

49 reduction of physical activity results in rising obesity prevalence worldwide (World Health Organization). According to the National Basic Health Survey, obesity prevalence in Indonesia increases by $4.3 \%$ from 2007 to 2013, and 7\% from 2013 to 2018, respectively (RISKESDAS, 2007, 2013, 2018). As a known leading risk factor for chronic non-communicable diseases (such as hypertension, type 2 diabetes mellitus (T2DM), cardiovascular diseases (CVD), fatty liver, stroke, and some types of cancers), obesity contributes to economy and health burdens (Must et al., 1999; Basen-Engquist \& Chang, 2011; Al-Goblan, Al-Alfi \& Khan, 2014). As the risk of these chronic diseases increases and the quality of life decreases, the health care costs escalate (Withrow \& Alter, 2011; Cawley \& Meyerhoefer, 2012).

The complex interplay between environmental and multiple genetic factors that influence body mass index (BMI) has been proposed to trigger increased obesity and its comorbidities prevalences, with heritability estimated to be around 40-70\% (Herrera \& Lindgren, 2010). Among the significant obesity genetic risk factors, the common single nucleotide polymorphisms (SNPs) rs9939609 and rs1421085 in the fat mass and obesity-associated (FTO) gene have been consistently reported to be associated with obesity in distinct populations (Chang et al., 2008; Cha et al., 2008; Fawwad et al., 2015; Babenko et al., 2019).

67 Bali population has undergone rapid lifestyle transition from traditional to modern lifestyle in 8 line with Bali's escalating economic growth, most likely due to the increased tourism industry 9 (Antara \& Sumarniasih, 2017). Several studies showed the adoption of western diet, reduction of 70 physical activities, increasing in socio-economic status and education are associated with 
71 increase in adiposity (Huntsman, White \& Gunung, 2005) and high obesity prevalence in the

urban population (Suastika et al., 2011b). The obesity prevalence in Bali was $15.5 \%$, higher than Indonesian obesity prevalence (14.8\%) in 2013 (RISKESDAS, 2013). The interplay between genetics and lifestyle factors has been reported to contribute to obesity and its comorbidities in this population (Malik et al. 2011, Oktavianthi et al. 2012). In this study, we examined the association of FTO rs9939609 and rs1421085 with obesity in the Balinese of the Bali Province, Indonesia. We hypothesize that FTO gene variants play a role in modulating the increased of BMI and obesity risk in the Balinese.

\section{Materials and Methods}

\section{Subjects, Study Design, Measurements}

A cross-sectional study enrolling 612 participants from five locations (286 female and 326 male) in Bali Province, Indonesia, was conducted in 2008-2015 with written informed consent (Malik et al., 2011; Suastika et al., 2011b; Oktavianthi et al., 2012, 2018). The five locations represents urban (Legian and Denpasar) and rural (Penglipuran, Nusa Ceningan and Pedawa) settings, based on Statistics Indonesia's criteria (Badan Pusat Statistik, 2010). The map and sample size of the five locations are shown in Supplementary Figure S1. Ethical approvals for this study were granted by the Eijkman Institute Research Ethics Commission (no. 32 on 27 October 2008 and no. 80 on 24 December 2014), and by the Faculty of Medicine Ethic Committee, Universitas Udayana (no. 690a/SKRT/X/2010 on 28 October 2010 and no. 1286/UN.14.2/Litbang/2014 on 18 September 2014). Collected demographic and anthropometric data include: age, gender, weight, height, and waist circumference (WC). Body mass index (BMI) was calculated as weight in $\mathrm{kg}$ divided by (height) ${ }^{2}$ in $\mathrm{m}^{2}$, while waist to height ratio (WHtR) was calculated as WC divided by height, both measured in the same unit. WHtR is a proxy for central (visceral) adipose 
95 tissue (Swainson et al., 2017). The high BMI (BMI $\geq 25 \mathrm{~kg} / \mathrm{m}^{2}$ ) and high $\mathrm{WC}$ (male $\geq 90 \mathrm{~cm}$;

96 female $\geq 80 \mathrm{~cm}$ ) cut offs were according to the Asia-Pacific perspective redefining obesity in

97 adult Asian, while the high WHtR cut off at $\geq 0.5$ was based on previous reports (Lee et al.,

98 1995; Hsieh \& Yoshinaga, 1995; WHO Regional Office for the Western Pacific, 2000).

\section{DNA extraction and genotyping}

101 Genomic DNA was extracted as previously described (Malik et al., 2011). The FTO rs9939609 and rs1421085 variants were detected using amplification-refractory mutation system (ARMS) polymerase chain reaction (PCR). Detection of rs9939609 was performed using a previously published primer sets (Fawwad et al., 2015) while detection of rs1421085 was done using a novel primer sets, designed using Primer1 (Collins \& Ke, 2012) and BioEdit ${ }^{\circledR}$ Sequence ARMS-PCR is described in Supplementary Table S1. Optimation of the annealing temperature was done using the Veriti ${ }^{\circledR} 96$ West Thermal Cycler [Applied Biosystem], while the ARMSPCR was performed using GeneAmp® PCR System 9700 (Applied Biosystems, Foster City, CA, USA). ARMS-PCR conditions are described in Supplementary Table S1. PCR products variant alleles were carried out by DNA sequencing using BigDye ${ }^{\circledR}$ Terminator v.3.1 Cycle Sequencing Kits, with ABI 3130xl Genetic Analyzer (Applied Biosystem).

\section{Statistical analysis}

116 Statistical analysis were carried out in R version 3.4.0 (www.r-project.org) with RStudio version 117 1.0.143 (www.rstudio.com). The five sampling sites (four villages and one city) map was 
118 generated from Google Static Maps using the "ggmap" and "ggrepel" packages. Continuous

119 variables are presented as mean $( \pm \mathrm{SD})$. All SNPs were tested for departure from

120 Hardy-Weinberg equilibrium (HWE). Genotype distributions and linkage disequilibrium (LD)

121 between SNP pairs were calculated using the "genetics" package (Warnes et al., 2019).

122 Haplotypes were determined using expectation maximization (EM) algorithm as implemented

123 in the "haplo.glm" function of the R "haplo.stats" library. Genetic associations analyses were

124 conducted using both linear and logistic regression models with adjustments for age and gender

125 (male/female). Significant level based on Bonferroni correction was set at 0.025 ( $p$ value $=$

126 0.050/2) (Nichols \& Hayasaka, 2003).

127

128 Results

\section{The Balinese characteristics}

130 The characteristics of the study subjects are summarized in Table 1 . The male to female ratio

131 was comparable (53.3\% vs. 46.7\%). The Balinese showed a rather high mean of obesity 132 parameter values $\left(B M I 24.0 \pm 4.83 \mathrm{~kg} / \mathrm{m}^{2}\right.$; WC $83.9 \pm 11.6 \mathrm{~cm}$; WHtR $\left.0.53 \pm 0.07\right)$. Genotype 133 distribution for rs 9939609 is TT 34\%, TA 49\%, and AA 17\%; while for rs 1421085 is TT $37 \%$, 134 TC 46\%, and CC 18\%. Minor allele frequency (MAF) for both variants were 0.42 and 0.41 , 135 respectively (Table 1). The rs9939609 and rs1421085 presented a high linkage disequilibrium 136 with $\mathrm{D}^{\prime}=0.90$ and $\mathrm{r}^{2}=0.88$.

137

FTO rs9939609 and FTO rs1421085 SNPs are associated with obesity

139 Of all the genetic models developed (Table S2 and S3), the recessive model was the most 140 suitable for this population. In multiple linear regression analyses with recessive genetic model, 
141 the minor rs9939609 AA and rs1421085 CC genotypes increased BMI by $1.25 \mathrm{~kg} / \mathrm{m}^{2}(p=0.012)$

142 and by $1.12 \mathrm{~kg} / \mathrm{m}^{2}(p=0.022)$, respectively. Multiple logistic regression results further

143 confirmed these tendencies of increasing the odds of high BMI in subjects carrying the minor

144 genotypes of both SNPs (odds ratio $=1.59, p=0.042$ for rs9939609; and odds ratio $=1.57, p=$

1450.047 for rs1421085). Of the non-genetic parameters, age was shown to influence BMI, and

146 being male increased BMI and WC, while living in an urban setting increased all obesity 147 parameters (Table 2).

149 To investigate the involvement of gender and environmental setting in relationship to FTO SNPs and obesity parameters, we conducted separate association analyses in male and female subjects

151 (Table S4 and S5), as well as in urban and rural populations (Table S6 and S7). The significant associations between rs9939609 AA and the rs1421085 CC genotypes and increased BMI were only found in females in both linear (estimate $=1.97 \mathrm{~kg} / \mathrm{m}^{2}$ and $p=0.021$ for rs9939609 AA, estimate $=2.35 \mathrm{~kg} / \mathrm{m}^{2}$ and $p=0.005$ for $\mathrm{rs} 1421085 \mathrm{CC}$ genotypes) and logistic (odds ratio $=2.83$ and $p=0.003$ for rs9939609 AA, odds ratio $=3.36$ and $p=0.001$ for rs1421085 CC genotypes) regression analyses (Table 3).

These genotypes also presented distinct effects on obesity parameters in different environmental setting, as shown in Table 4. In urban, increased WC was inclined to be associated with the rs9939609 AA genotype in linear regression analysis (estimate $=3.04 \mathrm{~cm}, p=0.038$ ), and with the rs1421085 $\mathrm{CC}$ genotypes in logistic (odds ratio $=1.95, p=0.037$ ) regression analyses.

162 Meanwhile in rural, rs9939609 AA showed a tendency to increase BMI by $1.53 \mathrm{~kg} / \mathrm{m}^{2}$ and the 
163 rs 1421085 CC genotypes demonstrated a significantly increased BMI by $1.65 \mathrm{~kg} / \mathrm{m}^{2}(p=0.016)$,

164 and higher odds for high BMI (odds ratio $=2.25$ and $p=0.016$ ).

165

166 In haplotype analyses incorporating recessive genetic model, the AC haplotype consisting the

167 minor alleles A of rs9939609 and C of rs1421085 was associated with obesity parameters (BMI

168 by $0.73 \mathrm{~kg} / \mathrm{m}^{2}(p=0.008)$, WC by $1.47 \mathrm{~cm}(p=0.022)$, respectively (Table S8). The AC

169 haplotype demonstrated a tendency for increased WC by $1.99 \mathrm{~cm}(p=0.041)$ in females (Table

170 S9), and was also associated with increased BMI in rural population (Table S10).

171

172

FTO rs9939609 and FTO rs1421085 SNPs maintained high BMI in subjects older than the

173

mean age of $\geq 46.6$ years

174

The mean age of this population is 46.6 years old (Table 1). Our result showed that the obesity 175 parameters (BMI, WC and WHtR) in subjects $<46.6$ years have a tendency to increase, while in subjects $\geq 46.6$ years, they have a tendency to decrease (Figure 1). Interestingly, subjects carrying the homozygous variants of both SNPs (rs9930609 AA and rs1421085 CC genotypes) sustained their high BMI regardless of their age, in contrast to the wild-type and heterozygous genotypes carriers which demonstrated a trend toward decreasing BMI with age. Meanwhile, the relationships between WC and WHtR and age are not modulated by the FTO genotypes (Figure 1).

\section{Discussion}

Association studies of the FTO gene with obesity or obesity-related traits have been reported in many populations across the world, confirming the strong association of FTO SNPs with BMI 
186 and/or obesity (Frayling et al., 2007; Scuteri et al., 2007; Hotta et al., 2008; Chang et al., 2008;

187 Srivastava et al., 2016). A meta-analyses study demonstrated the correlation between FTO 188 rs9939609 and rs1421085 with obesity in Hispanic, Caucasian, and Asian populations (Peng et 189 al., 2011).

190

191

In Indonesian population, most report on FTO rs9939609 SNP association with obesity came 192 from the western part of the country, namely North Sumatera (Lubis et al., 2017), Yogyakarta (Iskandar et al., 2018), West Sumatera (Susmiati et al., 2018), and DKI Jakarta (Daya et al., 194 2019). Despite the diversity of the Indonesian population (Karafet et al., 2010; Tumonggor et al., 2013) and the differences in sociocultural exposure, our report from Bali, which is located in the central part of Indonesia, showed that the FTO variants are also genetic risk factors for obesity in the Balinese, similar to previously reported populations from the western part of Indonesia.

In this study, we showed that having the FTO rs9939609 and rs1421085 SNPs risk alleles increase the risk for obesity. We have reported recently that individuals carrying the risk allele of rs9939609 demonstrated a higher risk to develop obesity due to preferences for high dietary fat intake (Daya et al., 2019). FTO might play a role in controlling feeding behaviour and energy expenditure (Fawcett \& Barroso, 2010), the reduced of satiety responsiveness (Wardle et al., 2008), higher consumption of highly palatable food (Wardle et al., 2009), and loss of control over eating (Tanofsky-Kraff et al., 2009). Another study suggested a link between FTO, protein intake, and body weight (Merritt, Jamnik \& El-Sohemy, 2018). All of these might influence the different effects of FTO on female vs. male, and urban vs. rural. In this study, we did not assess food intake, which is the limitation of this study. 
210 Our current report indicated a gender-specific effect, where the associations of the A allele of

211

212

213

214

215

216

217

218

219

220

221

222

223

224

225

226

227

228

229

230

231 rs9939609 and the C allele of rs14210845 with BMI were stronger in female than in male. These findings were consistent with previous studies in children and adolescents in Swedish and Chinese population (Jacobsson et al., 2008; Zhang et al., 2014). A meta-analysis study has found that 25 FTO SNPs including rs9939609 and rs1421085, were specifically associated with obesity in females only (Tan et al., 2014). This gender differences might be explained by the variation in body composition between males and females (Zillikens et al., 2008). A comparative study of twins in eight countries reported that there is a gender differences in the heritability of BMI (Schousboe et al., 2003). However, other studies have reported that the rs9939609 was associated with BMI in both gender (Frayling et al., 2007; Qi et al., 2008). These discrepancies may be due to distinct genetic background, environmental factors and sample sizes. Moderate sample size is another limitation of this study. Population-based studies with large sample size will be beneficial for further investigation of the possible interactions between FTO SNPs and genders.

In general the Balinese BMI tend to decrease by age, however, our result showed that high BMI is maintained in individual carrying the FTO rs9939609 and rs1421085 risk alleles. This may imply the long-lasting effect of FTO risk alleles in increasing the obesity risk, regardless of the age. The basal metabolic rate decreases along with age and will lead to metabolic abnormality (Henry, 2000). Our previous study showed that metabolic decline is more prominent in Balinese older subjects (Suastika et al., 2011a). Thus, awareness to maintain healthy lifestyle should begin from younger age to prevent obesity and its related comorbidities. A survey of nutritional habits 
232 in teenagers reported that eating errors (i.e. irregular eating, skipping breakfast) were more

233 frequently observed in overweight and student having obesity as compared to the normal weight

234 ones, and emphasized the importance of conveying the knowledge on the causes of overweight

235 and obesity and the rules of healthy dieting (Zalewska \& Maciorkowska, 2017).

236

237 Our previous studies in Balinese showed that the associations between genetic risk factors and 238 obesity were different in urban dan rural area. In this study and our previous study of ADRB3 SNP showed that the association between genetic risk factor and obesity were found in rural (Malik et al., 2011). However, the association between UCP2 genetic risk factors and obesity was only found in urban (Oktavianthi et al., 2012). Discrepancies between urban and rural might be due to the influence of lifestyle and environmental exposures, as well as gene-environment interaction. Urban and rural have their own environmental characteristics. The characteristics of urban area include population density of $\geq 5,000$ persons $/ \mathrm{km}^{2}$, less than $25 \%$ work in the agricultural sector and have more than 8 public facilities (i.e. high school, health center, roads that can accommodate 4 wheeled motorized vehicles, factories, etc.). The characteristic of rural area include population density of $<1000$ and most of the land are used for farming (Mulyana, 2014). All of these might influence their lifestyle, from being active and hardworking as farmers or fishermen into less active as hotel worker or small store owners. Urban people also consume more ready-to-eat food and their food variation are lower than rural (Ghaisani, 2017).

Obesity is influenced by a complex interplay between multiple genes and environmental risk factors, such as consumption of high energy dense food and sedentary lifestyle. These powerful combination might predispose the high prevalence of obesity in urbans, which increased the risk 
255 to develop non-communicable disease. Nevertheless, a recent report revealed that contrary to the

256 major views, more than $80 \%$ of the global rise in mean BMI from 1985 to 2017 in some low- and

257 middle-income countries was accounted for BMI increases in rural areas (NCD Risk Factor

258 Collaboration (NCD-RisC), 2019).

259

\section{Conclusion}

261 The Balinese population showed a high MAF of the FTO rs9939609 and rs1421085 risk alleles

262 that were associated with increased BMI and obesity. Considering that these risk alleles could

263 have a long-lasting effect in this population, knowledge on healthy lifestyle and diet should be

264 introduced and endorsed not only to the urban Balinese, but also to the rural population, although

265 their average BMI are still within the normal range.

266

267 Additional Information and declarations

268 Funding

269 The research was supported by the block grant from the Government of Republic of Indonesia

270 through the Ministry of Research, Technology and Higher Education for the Eijkman Institute

271 for Molecular Biology.

272

273 Competing Interests

274 The authors declare there are no competing interests.

275

276

Author Contributions 
277 - Lidwina Priliani designed the experiments, analyzed the data, wrote the paper, prepared 278 figures and/or tables, and reviewed drafts of the paper.

279 - Sukma Oktavianthi analyzed the data, contributed reagents/materials/analysis tools, wrote the 280 paper, prepared figures and/or tables, and reviewed drafts of the paper.

281 - Ria Hasnita, Hazrina T. Nussa, Rut C. Inggriani, performed the experiments and data 282 analyses.

283 - Clarissa A. Febinia and Ketut Suastika contributed reagents/materials/analysis tools, and 284 reviewed drafts of the paper.

285 - Anom Bowolaksono, Rini Puspitaningrum and Rully A. Nugroho reviewed drafts of the 286 paper.

287 - Safarina G. Malik conceived and designed the study, analyzed the data, contributed 288 reagents/materials/analysis tools, wrote the paper, reviewed drafts of the paper.

\section{Human Ethics}

291 The following information was supplied relating to ethical approvals (i.e., approving body and 292 any reference numbers):

293 Ethical approvals for this study were granted by the Eijkman Institute Research Ethics 294 Commission (no. 32 on 27 October 2008 and no. 80 on 24 December 2014 ), and by the Faculty 295 of Medicine Ethic Committee, Universitas Udayana (no. 690a/SKRT/X/2010 on 28 October 2962010 and no. 1286/UN.14.2/Litbang/20140 18 September 2014).

\section{Acknowledgement}


299 The authors are grateful to all volunteers for their participation in this study. The authors thanked

300 Drs. Made Ratna Saraswati, Pande Dwipayana, Desak Made Wihandani, and I Wayan Weta for

301 their support during sample collections. We thanked the field medical doctors, medical faculty

302 students, clinical pathology laboratory and research assistants for their support in this study. We

303 thanked dr. Ni Luh Made Agustini Leonita for her help in DNA isolation. We are grateful to

304 Profs. Herawati Sudoyo and Sangkot Marzuki for their support and encouragements.

305

306

307

308

309

310

311

\section{References}

Al-Goblan AS, Al-Alfi MA, Khan MZ. 2014. Mechanism linking diabetes mellitus and obesity. Diabetes, Metabolic Syndrome and Obesity: Targets and Therapy 7:587-591. DOI: 10.2147/DMSO.S67400.

Antara M, Sumarniasih MS. 2017. Role of Tourism in Economy of Bali and Indonesia. Journal of Tourism and Hospitality Management 5. DOI: 10.15640/jthm.v5n2a4.

312

313

Babenko V, Babenko R, Gamieldien J, Markel A. 2019. FTO haplotyping underlines high obesity risk for European populations. BMC medical genomics 12:46. DOI: 10.1186/s12920-019-0491-X.

Badan Pusat Statistik. 2010. Peraturan kepala badan pusat statistik nomor 37 tahun 2010 tentang klasifikasi perkotaan dan perdesaan di Indonesia. Buku 3. Bali, Nusa Tenggara, Kalimantan, Sulawesi, Maluku dan Papua. Badan Pusat Statistik.

Basen-Engquist K, Chang M. 2011. Obesity and Cancer Risk: Recent Review and Evidence. Current oncology reports 13:71-76. DOI: 10.1007/s11912-010-0139-7. 
320 Cawley J, Meyerhoefer C. 2012. The medical care costs of obesity: an instrumental variables

321

322

323

324

325

326

327

328

329

330

331

332

333

334

335

336

337

338

339

340

341

342

approach. Journal of Health Economics 31:219-230. DOI:

10.1016/j.jhealeco.2011.10.003.

Cha SW, Choi SM, Kim KS, Park BL, Kim JR, Kim JY, Shin HD. 2008. Replication of genetic effects of FTO polymorphisms on BMI in a Korean population. Obesity (Silver Spring, Md.) 16:2187-2189. DOI: 10.1038/oby.2008.314.

Chang Y-C, Liu P-H, Lee W-J, Chang T-J, Jiang Y-D, Li H-Y, Kuo S-S, Lee K-C, Chuang L-M. 2008. Common Variation in the Fat Mass and Obesity-Associated (FTO) Gene Confers Risk of Obesity and Modulates BMI in the Chinese Population. Diabetes 57:2245-2252. DOI: $10.2337 / \mathrm{db} 08-0377$.

Collins A, Ke X. 2012. Primer1: Primer design Web service for Tetra-Primer ARMS-PCR. The Open Bioinformatics Journal 6:55-58. DOI: Collins, Andrew and Ke, Xiayi Primer1: Primer design Web service for Tetra-Primer ARMS-PCR. The Open Bioinformatics Journal, 6, 55-58. (doi:10.2174/1875036201206010055 $<$ http://dx.doi.org/10.2174/1875036201206010055>).

Daya M, Pujianto DA, Witjaksono F, Priliani L, Susanto J, Lukito W, Malik SG. 2019. Obesity risk and preference for high dietary fat intake are determined by FTO rs9939609 gene polymorphism in selected Indonesian adults. Asia Pacific Journal of Clinical Nutrition 28:183-191. DOI: 10.6133/apjcn.201903_28(1).0024.

Fawcett KA, Barroso I. 2010. The genetics of obesity: FTO leads the way. Trends in genetics: TIG 26:266-274. DOI: 10.1016/j.tig.2010.02.006.

Fawwad A, Siddiqui IA, Zeeshan NF, Shahid SM, Basit A. 2015. Association of SNP rs9939609 in FTO gene with metabolic syndrome in type 2 diabetic subjects, rectruited from a 
tertiary care unit of Karachi, Pakistan. Pakistan Journal of Medical Sciences 31:140-145. DOI: 10.12669/pjms.311.6524.

345

Frayling TM, Timpson NJ, Weedon MN, Zeggini E, Freathy RM, Lindgren CM, Perry JRB, Elliott KS, Lango H, Rayner NW, Shields B, Harries LW, Barrett JC, Ellard S, Groves CJ, Knight B, Patch A-M, Ness AR, Ebrahim S, Lawlor DA, Ring SM, Ben-Shlomo Y, Jarvelin M-R, Sovio U, Bennett AJ, Melzer D, Ferrucci L, Loos RJF, Barroso I, Wareham NJ, Karpe F, Owen KR, Cardon LR, Walker M, Hitman GA, Palmer CNA, Doney ASF, Morris AD, Smith GD, Hattersley AT, McCarthy MI. 2007. A common variant in the FTO gene is associated with body mass index and predisposes to childhood and adult obesity. Science (New York, N.Y.) 316:889-894. DOI: 10.1126/science. 1141634 .

Ghaisani L. 2017. Perkembangan Pola Konsumsi Pangan menurut Wilayah dan Tingkat Pendapatan di Provinsi Bali Tahun 2009-2015. Bogor: Institute Pertanian Bogor.

Henry CJ. 2000. Mechanisms of changes in basal metabolism during ageing. European Journal of Clinical Nutrition 54 Suppl 3:S77-91.

Herrera BM, Lindgren CM. 2010. The Genetics of Obesity. Current Diabetes Reports 10:498505. DOI: $10.1007 / \mathrm{s} 11892-010-0153-\mathrm{z}$.

Hotta K, Nakata Y, Matsuo T, Kamohara S, Kotani K, Komatsu R, Itoh N, Mineo I, Wada J, Masuzaki H, Yoneda M, Nakajima A, Miyazaki S, Tokunaga K, Kawamoto M, Funahashi T, Hamaguchi K, Yamada K, Hanafusa T, Oikawa S, Yoshimatsu H, Nakao K, Sakata T, Matsuzawa Y, Tanaka K, Kamatani N, Nakamura Y. 2008. Variations in the FTO gene are associated with severe obesity in the Japanese. Journal of Human Genetics 53:546-553. DOI: 10.1007/s10038-008-0283-1. 
366 Hsieh SD, Yoshinaga H. 1995. Abdominal fat distribution and coronary heart disease risk factors

367

368

369

370

371

372

373

374

375

376

377

378

379

380

381

382

383

384

385

386

387 in men-waist/height ratio as a simple and useful predictor. International Journal of Obesity and Related Metabolic Disorders: Journal of the International Association for the Study of Obesity 19:585-589.

Huntsman AC, White NG, Gunung K. 2005. Anthropometry, lifestyles and fat patterning in Balinese women. Annals of Human Biology 32:599-619. DOI: $10.1080 / 03014460500234244$.

Iskandar K, Patria SY, Huriyati E, Luglio HF, Julia M, Susilowati R. 2018. Effect of FTO rs9939609 variant on insulin resistance in obese female adolescents. BMC Research Notes 11:300. DOI: 10.1186/s13104-018-3392-8.

Jacobsson JA, Danielsson P, Svensson V, Klovins J, Gyllensten U, Marcus C, Schiöth HB, Fredriksson R. 2008. Major gender difference in association of FTO gene variant among severely obese children with obesity and obesity related phenotypes. Biochemical and Biophysical Research Communications 368:476-482. DOI: 10.1016/j.bbrc.2008.01.087.

Karafet TM, Hallmark B, Cox MP, Sudoyo H, Downey S, Lansing JS, Hammer MF. 2010. Major east-west division underlies Y chromosome stratification across Indonesia. Molecular Biology and Evolution 27:1833-1844. DOI: 10.1093/molbev/msq063.

Lee JS, Aoki K, Kawakubo K, Gunji A. 1995. A study on indices of body fat distribution for screening for obesity. Sangyo Eiseigaku Zasshi = Journal of Occupational Health 37:918.

Lubis SM, Fattah M, Damanik HA, Batubara JRL. 2017. Association of Fat Mass and Obesityassociated Gene (FTO) rs9939609 Variant with Early Onset Obesity among Bataknese

Peer] reviewing PDF | (2019:08:40197:1:1:NEW 8 Nov 2019) 
and Chinese Children in Indonesia: A Case-control Study. The Indonesian Biomedical Journal 9:147-52. DOI: 10.18585/inabj.v9i3.322.

390

391

392

393

394

395

396

397

398

399

400

401

402

403

404

405

406

407

408

409

Malik SG, Saraswati MR, Suastika K, Trimarsanto H, Oktavianthi S, Sudoyo H. 2011. Association of beta3-adrenergic receptor (ADRB3) Trp64Arg gene polymorphism with obesity and metabolic syndrome in the Balinese: a pilot study. BMC research notes 4:1. DOI: $10.1186 / 1756-0500-4-167$.

Merritt DC, Jamnik J, El-Sohemy A. 2018. FTO genotype, dietary protein intake, and body weight in a multiethnic population of young adults: a cross-sectional study. Genes \& Nutrition 13. DOI: 10.1186/s12263-018-0593-7.

Mulyana W. 2014. Rural-Urban Linkages: Indonesia Case Study. In: Working Paper Series $N^{o}$ 126. Working Group: Development with Territorial Cohesion. Territorial Cohesion for Development Program. Rimisp, Santiago, Chile,.

Must A, Spadano J, Coakley EH, Field AE, Colditz G, Dietz WH. 1999. The disease burden associated with overweight and obesity. JAMA 282:1523-1529.

NCD Risk Factor Collaboration (NCD-RisC). 2019. Rising rural body-mass index is the main driver of the global obesity epidemic in adults. Nature 569:260-264. DOI: 10.1038/s41586-019-1171-X.

Nichols T, Hayasaka S. 2003. Controlling the familywise error rate in functional neuroimaging: a comparative review. Statistical Methods in Medical Research 12:419-446. DOI: 10.1191/0962280203sm341ra.

Oktavianthi S, Saraswati MR, Suastika K, Dwipayana P, Sulfianti A, Hayati RF, Trimarsanto H, Febinia CA, Sudoyo H, Malik SG. 2018. Transcription factor 7-like 2 single nucleotide 
polymorphisms are associated with lipid profile in the Balinese. Molecular Biology

411 Reports 45:1135-1143. DOI: 10.1007/s11033-018-4265-х.

412

413

414

415

416

417

418

419

420

421

422

423

424

425

426

427

428

429

430

431

Oktavianthi S, Trimarsanto H, Febinia CA, Suastika K, Saraswati MR, Dwipayana P, Arindrarto W, Sudoyo H, Malik SG. 2012. Uncoupling protein 2 gene polymorphisms are associated with obesity. Cardiovascular Diabetology 11:41. DOI: 10.1186/1475-2840-11-41.

Peng S, Zhu Y, Xu F, Ren X, Li X, Lai M. 2011. FTO gene polymorphisms and obesity risk: a meta-analysis. BMC medicine 9:71. DOI: 10.1186/1741-7015-9-71.

Qi L, Kang K, Zhang C, van Dam RM, Kraft P, Hunter D, Lee C-H, Hu FB. 2008. Fat Mass-and Obesity-Associated (FTO) Gene Variant Is Associated With Obesity. Diabetes 57:31453151. DOI: $10.2337 / \mathrm{db} 08-0006$.

RISKESDAS. 2007. Riset Kesehatan Dasar. Badan Penelitian dan Pengembangan Kesehatan, Kementerian Kesehatan Republik Indonesia.

RISKESDAS. 2013. Riset Kesehatan Dasar. Badan Penelitian dan Pengembangan Kesehatan, Kementerian Kesehatan Republik Indonesia.

RISKESDAS. 2018. Riset Kesehatan Dasar. Badan Penelitian dan Pengembangan Kesehatan, Kementerian Kesehatan Republik Indonesia.

Schousboe K, Willemsen G, Kyvik KO, Mortensen J, Boomsma DI, Cornes BK, Davis CJ, Fagnani C, Hjelmborg J, Kaprio J, De Lange M, Luciano M, Martin NG, Pedersen N, Pietiläinen KH, Rissanen A, Saarni S, Sørensen TIA, Van Baal GCM, Harris JR. 2003. Sex differences in heritability of BMI: a comparative study of results from twin studies in eight countries. Twin Research: The Official Journal of the International Society for Twin Studies 6:409-421. DOI: 10.1375/136905203770326411. 
432 Scuteri A, Sanna S, Chen W-M, Uda M, Albai G, Strait J, Najjar S, Nagaraja R, Orrú M, Usala

433

434

435

436

437

438

439

440

441

442

443

444

445

446

447

448

449

450

451

452

G, Dei M, Lai S, Maschio A, Busonero F, Mulas A, Ehret GB, Fink AA, Weder AB,

Cooper RS, Galan P, Chakravarti A, Schlessinger D, Cao A, Lakatta E, Abecasis GR.

2007. Genome-wide association scan shows genetic variants in the FTO gene are associated with obesity-related traits. PLoS genetics 3:e115. DOI:

10.1371/journal.pgen.0030115.

Srivastava A, Mittal B, Prakash J, Srivastava P, Srivastava N, Srivastava N. 2016. Association of FTO and IRX3 genetic variants to obesity risk in north India. Annals of Human Biology 43:451-456. DOI: 10.3109/03014460.2015.1103902.

Suastika K, Dwipayana P, Saraswati MR, Kuswardhani T, Astika N, Putrawan IB, Matsumoto K, Kajiwara N, Taniguchi H. 2011a. Relationship between age and metabolic disorders in the population of Bali. 2:47-52. DOI: 10.1016/j.jcgg.2011.03.001.

Suastika K, Gotera W, Budhiarta AA, Sutanegara IND, Gunadi IGN, Nadha KB, Wita W, Rina K, Santoso A, Matsumoto K, Kajiwara N, Taniguchi H. 2011b. Prevalence of obesity, metabolic syndrome, impaired fasting glycemia, and diabetes in selected villages of Bali, Indonesia. Journal of the ASEAN Federation of Endocrine Societies 26:159-162. DOI: 10.15605/jafes.026.02.14.

Susmiati, Lipoeto NI, Surono IS, Jamsari J. 2018. Association of Fat Mass and Obesityassociated rs9939609 Polymorphisms and Eating Behaviour and Food Preferences in Adolescent Minangkabau Girls - SciAlert Responsive Version. 17:471-479. DOI: 10.3923/pjn.2018.471.479.

Peer] reviewing PDF | (2019:08:40197:1:1:NEW 8 Nov 2019) 
453 Swainson MG, Batterham AM, Tsakirides C, Rutherford ZH, Hind K. 2017. Prediction of

454

455

456

457

458

459

460

461

462

463

464

465

466

467

468

469

470

471

472

473

474 whole-body fat percentage and visceral adipose tissue mass from five anthropometric variables. PloS One 12:e177175. DOI: 10.1371/journal.pone.0177175.

Tan L-J, Zhu H, He H, Wu K-H, Li J, Chen X-D, Zhang J-G, Shen H, Tian Q, Krousel-Wood M, Papasian CJ, Bouchard C, Pérusse L, Deng H-W. 2014. Replication of 6 obesity genes in a meta-analysis of genome-wide association studies from diverse ancestries. PloS One 9:e96149. DOI: 10.1371/journal.pone.0096149.

Tanofsky-Kraff M, Han JC, Anandalingam K, Shomaker LB, Columbo KM, Wolkoff LE, Kozlosky M, Elliott C, Ranzenhofer LM, Roza CA, Yanovski SZ, Yanovski JA. 2009. The FTO gene rs9939609 obesity-risk allele and loss of control over eating. The American Journal of Clinical Nutrition 90:1483-1488. DOI: 10.3945/ajen.2009.28439.

Tumonggor MK, Karafet TM, Hallmark B, Lansing JS, Sudoyo H, Hammer MF, Cox MP. 2013. The Indonesian archipelago: an ancient genetic highway linking Asia and the Pacific. Journal of Human Genetics 58:165-173. DOI: 10.1038/jhg.2012.154.

Wardle J, Carnell S, Haworth CMA, Farooqi IS, O’Rahilly S, Plomin R. 2008. Obesity associated genetic variation in FTO is associated with diminished satiety. The Journal of Clinical Endocrinology and Metabolism 93:3640-3643. DOI: 10.1210/jc.2008-0472.

Wardle J, Llewellyn C, Sanderson S, Plomin R. 2009. The FTO gene and measured food intake in children. International Journal of Obesity (2005) 33:42-45. DOI: 10.1038/ijo.2008.174.

Warnes G, Gorjanc with contributions from G, Leisch F, Man and M. 2019. genetics: Population Genetics. 
475 WHO Regional Office for the Western Pacific. 2000. The Asia-Pacific perspective : redefining 476 obesity and its treatment. Sydney: Health Communications Australia.

477 Withrow D, Alter DA. 2011. The economic burden of obesity worldwide: a systematic review of 478 the direct costs of obesity. Obesity Reviews: An Official Journal of the International Association for the Study of Obesity 12:131-141. DOI: 10.1111/j.1467789X.2009.00712.x.

World Health Organization.Obesity and overweight. Available at https://www.who.int/news-

483 Zalewska M, Maciorkowska E. 2017. Selected nutritional habits of teenagers associated with 484 overweight and obesity. PeerJ 5:e3681. DOI: 10.7717/peerj.3681.

485

486 room/fact-sheets/detail/obesity-and-overweight (accessed April 10, 2019). Zhang M, Zhao X, Cheng H, Wang L, Xi B, Shen Y, Hou D, Mi J. 2014. Age- and SexDependent Association between FTO rs9939609 and Obesity-Related Traits in Chinese Children and Adolescents. PLOS ONE 9:e97545. DOI: 10.1371/journal.pone.0097545.

Zillikens MC, Yazdanpanah M, Pardo LM, Rivadeneira F, Aulchenko YS, Oostra BA, Uitterlinden AG, Pols H a. P, van Duijn CM. 2008. Sex-specific genetic effects influence variation in body composition. Diabetologia 51:2233-2241. DOI: 10.1007/s00125-0081163-0. 
Figure 1

Association between obesity parameters and age within FTO SNPs alleles

Upper panel: FTO rs9939609 showing (A) BMI, (B) WC, and (C) WHtR. Lower panel: FTO rs1421085 showing (D) BMI, (E) WC, and (F) WHtR.

\section{FTO rs9939609}

A

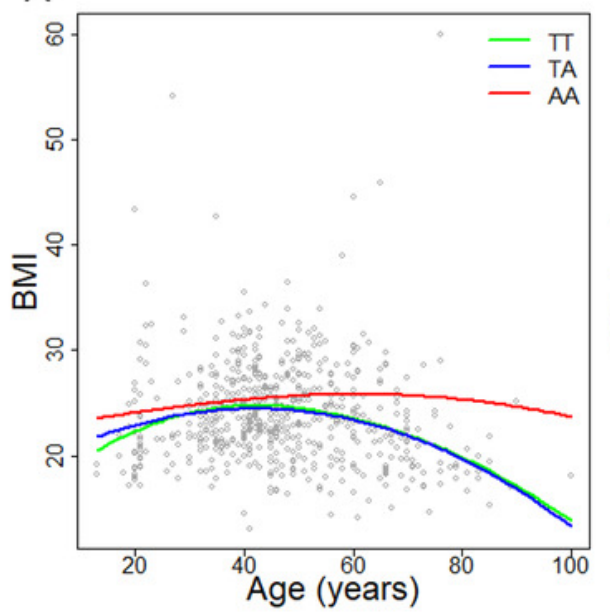

FTO rs1421085

D

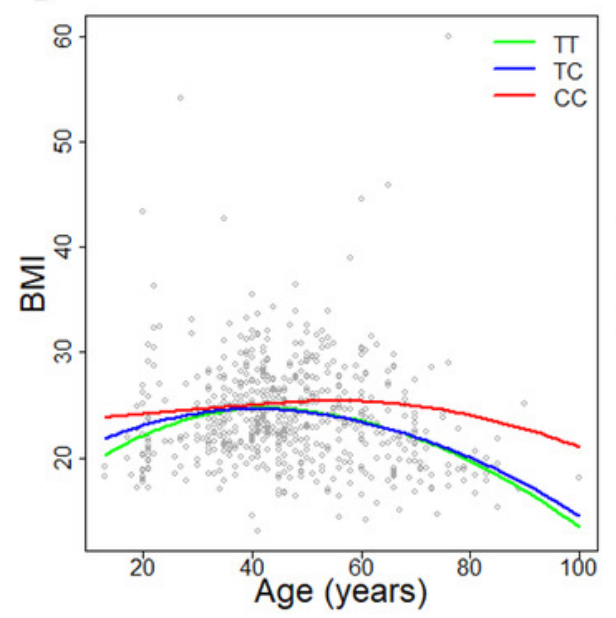

B

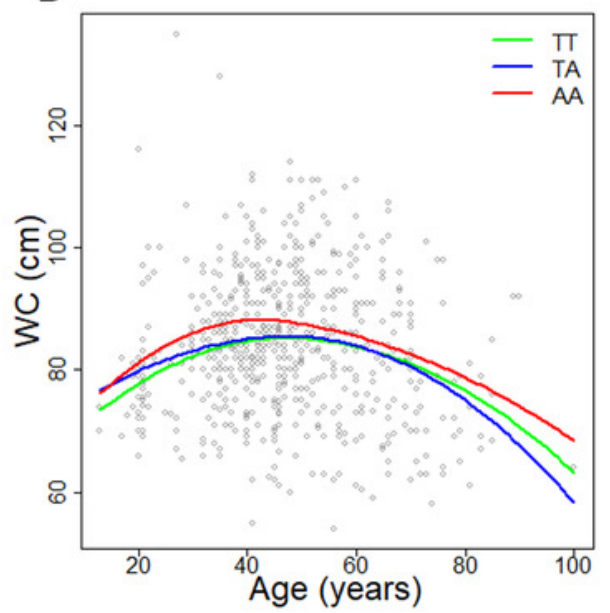

E

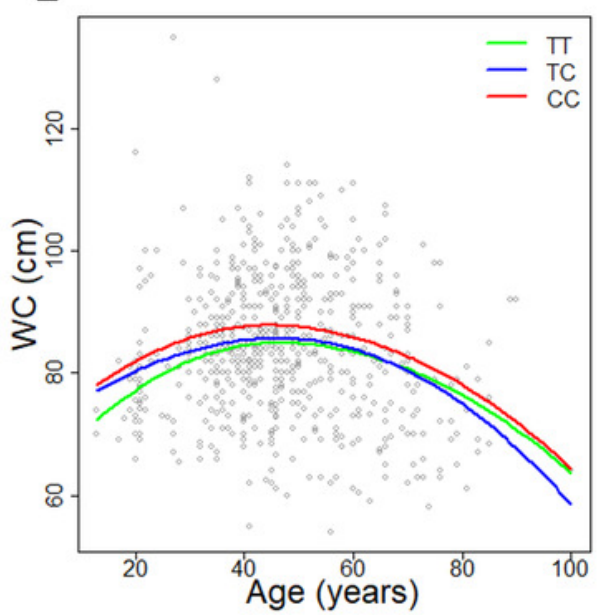

C

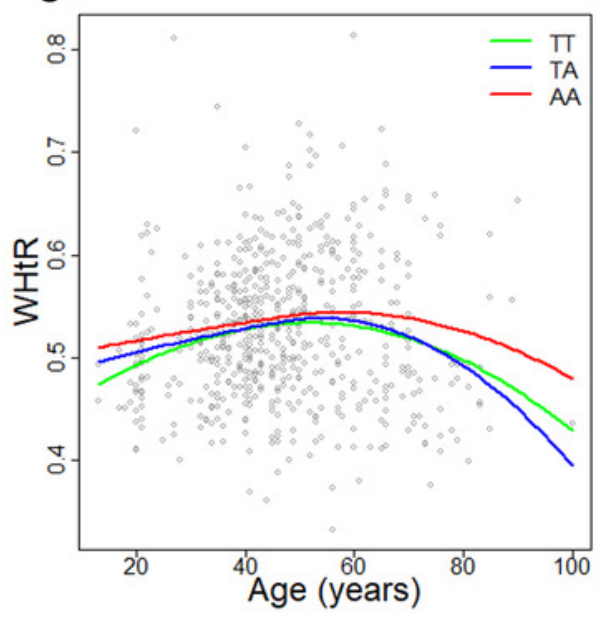

$\mathrm{F}$

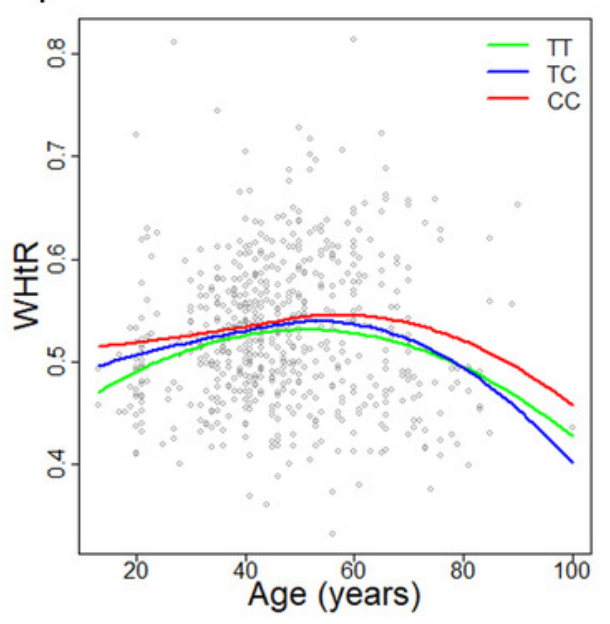




\section{Table $\mathbf{1}$ (on next page)}

Characteristics and genotypes of studied subjects

Data are presented as mean ( \pm SD) for age, weight, height BMI, WC, WHtR, and n (\%) for gender and genotypes frequency. BMI: body mass index, WC: waist circumference, WHtR: waist to height ratio, MAF: minor allele frequencies, HWE: Hardy Weinberg equilibrium, LD: linkage disequilibrium. $*_{n}(\%)$. The significant $p$-values are $<0.05$. 
1 Table 1. Characteristics and genotypes of studied subjects

\begin{tabular}{lccccc}
\hline Variables & $\begin{array}{c}\text { Total } \\
(\mathbf{n = 6 1 2})\end{array}$ & $\begin{array}{c}\text { Male } \\
(\mathbf{n}=\mathbf{3 2 6})\end{array}$ & $\begin{array}{c}\text { Female } \\
(\mathbf{n}=\mathbf{2 8 6})\end{array}$ & $\begin{array}{c}\text { Urban } \\
(\mathbf{n}=\mathbf{3 1 8})\end{array}$ & $\begin{array}{c}\text { Rural } \\
(\mathbf{n}=\mathbf{2 9 4})\end{array}$ \\
\hline Age (years) & $46.6 \pm 14.6$ & $47.9 \pm 13.1$ & $45.0 \pm 16.0$ & $42.8 \pm 12.7$ & $50.7 \pm 15.5$ \\
Weight (kg) & $61.4 \pm 14.6$ & $66.3 \pm 13.7$ & $55.7 \pm 13.6$ & $66.7 \pm 14.5$ & $55.6 \pm 12.4$ \\
Height (cm) & $159.0 \pm 8.9$ & $165.0 \pm 7.7$ & $154 \pm 6.1$ & $162.0 \pm 8.4$ & $157.0 \pm 8.7$ \\
BMI & $24.0 \pm 4.8$ & $24.4 \pm 4.5$ & $23.5 \pm 5.1$ & $25.4 \pm 4.7$ & $22.5 \pm 4.5$ \\
WC (cm) & $83.9 \pm 11.6$ & $86.5 \pm 11.4$ & $81.0 \pm 11.1$ & $87.5 \pm 11.2$ & $80.0 \pm 10.7$ \\
WHtR & $0.5 \pm 0.1$ & $0.5 \pm 0.1$ & $0.5 \pm 0.1$ & $0.5 \pm 0.1$ & $0.5 \pm 0.1$ \\
\hline FTO rs9939609*$*$ & & & & \\
TT & $208(34)$ & $103(32)$ & $105(37)$ & $116(36)$ & $92(31)$ \\
TA & $300(49)$ & $160(49)$ & $140(49)$ & $138(43)$ & $162(55)$ \\
AA & $104(17)$ & $63(19)$ & $41(14)$ & $64(20)$ & $40(14)$ \\
p-value HWE & 0.868 & 1 & 0.709 & 0.065 & 0.022 \\
MAF & 0.42 & 0.44 & 0.39 & 0.42 & 0.41 \\
\hline FTO rs1421085* & & & & & \\
TT & $224(37)$ & $114(35)$ & $110(38)$ & $126(40)$ & $98(33)$ \\
TC & $280(46)$ & $146(45)$ & $134(47)$ & $135(42)$ & $145(49)$ \\
CC & $108(18)$ & $66(20)$ & $42(15)$ & $57(18)$ & $51(17)$ \\
p-value HWE & 0.209 & 0.140 & 0.901 & 0.059 & 0.905 \\
MAF & 0.41 & 0.43 & 0.38 & 0.39 & 0.42 \\
\hline LD Corr & 0.88 & 0.87 & 0.90 & 0.88 & 0.89 \\
$\quad$ D' & 0.90 & 0.89 & 0.92 & 0.93 & 0.90 \\
\hline
\end{tabular}

2 Data are presented as mean ( \pm SD) for age, weight, height BMI, WC, WHtR, and $\mathrm{n}(\%)$ for gender 3 and genotypes frequency. BMI: body mass index, WC: waist circumference, WHtR: waist to 4 height ratio, MAF: minor allele frequencies, HWE: Hardy Weinberg equilibrium, LD: linkage 5 disequilibrium. ${ }^{*} \mathrm{n}(\%)$. The significant $p$-values are $<0.05$. 


\section{Table 2 (on next page)}

\section{Associations of FTO SNPs with obesity*}

*Recessive model. Statistical analysis was done using linear regression model, with adjustments for age, gender (male/female) and population (urban/rural). The model used for linear regression: outcome $\sim$ SNPs + age + gender + population. BMI: body mass index, WC: waist circumference, WHtR: waist to height ratio. High BMI: BMI $\geq 25$; High WC: male's WC $\geq$ $90 \mathrm{~cm}$ and female's WC $\geq 80 \mathrm{~cm}$; High WHtR: WHtR $\geq 0.5$. The significant $p$-values after Bonferroni correction are indicated in bold $(p<0.025)$. 
1 Table 2. Associations of FTO SNPs with obesity*

\begin{tabular}{|c|c|c|c|c|c|c|}
\hline \multirow[t]{2}{*}{$N=612$} & \multicolumn{2}{|c|}{ BMI } & \multicolumn{2}{|c|}{ WC } & \multicolumn{2}{|c|}{ WHtR } \\
\hline & Estimates & $p$ & Estimates & $p$ & Estimates & $p$ \\
\hline \multicolumn{7}{|c|}{ FTO rs9939609 } \\
\hline $\mathrm{AA}$ & 1.25 & 0.012 & 1.51 & 0.190 & 0.01 & 0.363 \\
\hline Age (years) & -0.01 & 0.482 & 0.01 & 0.633 & $<0.01$ & 0.011 \\
\hline Male & 0.82 & 0.029 & 5.26 & $<0.001$ & $<0.01$ & 0.467 \\
\hline Urban & 2.73 & $<0.001$ & 7.49 & $<0.001$ & 0.03 & $<0.001$ \\
\hline \multicolumn{7}{|c|}{ FTO rs1421085 } \\
\hline $\mathrm{CC}$ & 1.12 & 0.022 & 1.86 & 0.102 & 0.01 & 0.156 \\
\hline Age (years) & -0.01 & 0.438 & 0.01 & 0.679 & $<0.01$ & 0.013 \\
\hline Male & 0.82 & 0.029 & 5.24 & $<0.001$ & $<0.01$ & 0.444 \\
\hline Urban & 2.80 & $<0.001$ & 7.56 & $<0.001$ & 0.03 & $<0.001$ \\
\hline \multirow[t]{2}{*}{$N=612$} & \multicolumn{2}{|c|}{ High BMI } & \multicolumn{2}{|c|}{ High WC } & \multicolumn{2}{|c|}{ High WHtR } \\
\hline & $\begin{array}{l}\text { Odds } \\
\text { Ratio }\end{array}$ & $p$ & $\begin{array}{l}\text { Odds } \\
\text { Ratio }\end{array}$ & $p$ & $\begin{array}{l}\text { Odds } \\
\text { Ratio }\end{array}$ & $p$ \\
\hline \multicolumn{7}{|c|}{ FTO rs9939609 } \\
\hline $\mathrm{AA}$ & 1.59 & 0.042 & 1.31 & 0.228 & 1.17 & 0.506 \\
\hline Age (years) & 1.00 & 0.800 & 1.01 & 0.260 & 1.00 & 0.546 \\
\hline Male & 1.67 & 0.004 & 0.53 & $<0.001$ & 0.94 & 0.714 \\
\hline Urban & 3.14 & $<0.001$ & 2.77 & $<0.001$ & 2.93 & $<0.001$ \\
\hline \multicolumn{7}{|c|}{ FTO rs1421085 } \\
\hline $\mathrm{CC}$ & 1.57 & 0.047 & 1.52 & 0.060 & 1.49 & 0.090 \\
\hline Age (years) & 1.00 & 0.745 & 1.01 & 0.294 & 1.00 & 0.600 \\
\hline Male & 1.67 & 0.004 & 0.53 & $<0.001$ & 0.93 & 0.664 \\
\hline Urban & 3.22 & $<0.001$ & 2.81 & $<0.001$ & 2.96 & $<0.001$ \\
\hline
\end{tabular}

2 *Recessive model. Statistical analysis was done using linear regression model, with adjustments 3 for age, gender (male/female) and population (urban/rural). The model used for linear regression: 4 outcome $\sim$ SNPs + age + gender + population. BMI: body mass index, WC: waist circumference, 5 WHtR: waist to height ratio. High BMI: BMI $\geq 25$; High WC: male's WC $\geq 90 \mathrm{~cm}$ and female's $6 \mathrm{WC} \geq 80 \mathrm{~cm}$; High WHtR: WHtR $\geq 0.5$. The significant $p$-values after Bonferroni correction are 7 indicated in bold $(p<0.025)$. 


\section{Table 3 (on next page)}

Associations of FTO SNPs with obesity in male vs. female*

*Recessive model. Statistical analysis was done using logistic regression model while adjusting for age and population (urban/rural). The model used for linear regression: outcome $\sim$ SNPs + age + population. BMI: body mass index, WC: waist circumference, WHtR: waist to height ratio. High BMI: $B M I \geq 25$; High WC: male's $W C \geq 90 \mathrm{~cm}$ and female's $W C \geq 80 \mathrm{~cm}$; High WHtR: WHtR $\geq 0.5$. The significant $p$-values after Bonferroni correction are indicated in bold $(p<0.025)$. 
Table 3. Associations of FTO SNPs with obesity in male vs. female*

\begin{tabular}{|c|c|c|c|c|c|c|c|c|c|c|c|c|}
\hline & \multicolumn{6}{|c|}{ Male $(n=326)$} & \multicolumn{6}{|c|}{ Female $(n=286)$} \\
\hline & \multicolumn{2}{|c|}{ BMI } & \multicolumn{2}{|c|}{ WC } & \multicolumn{2}{|c|}{ WHtR } & \multicolumn{2}{|c|}{ BMI } & \multicolumn{2}{|c|}{$\mathbf{W C}$} & \multicolumn{2}{|c|}{ WHtR } \\
\hline & Estimates & $p$ & Estimates & $p$ & Estimates & $p$ & Estimates & $p$ & Estimates & $p$ & Estimates & $p$ \\
\hline \multicolumn{13}{|l|}{ FTO rs9939609 } \\
\hline AA & 0.69 & 0.242 & 0.83 & 0.569 & $<0.01$ & 0.848 & 1.97 & 0.021 & 2.11 & 0.251 & 0.01 & 0.314 \\
\hline Age (years) & -0.02 & 0.186 & -0.04 & 0.341 & $<0.01$ & 0.331 & -0.01 & 0.715 & 0.04 & 0.369 & $<0.01$ & 0.053 \\
\hline Urban & 3.44 & $<0.001$ & 9.32 & $<0.001$ & 0.04 & $<0.001$ & 1.91 & 0.003 & 5.53 & $<0.001$ & 0.02 & 0.014 \\
\hline \multicolumn{13}{|l|}{ FTO rs1421085 } \\
\hline $\mathrm{CC}$ & 0.23 & 0.688 & 0.61 & 0.670 & $<0.01$ & 0.850 & 2.35 & 0.005 & 3.48 & 0.056 & 0.02 & 0.067 \\
\hline Age (years) & -0.02 & 0.168 & -0.04 & 0.323 & $<0.01$ & 0.337 & -0.01 & 0.693 & 0.04 & 0.395 & $<0.01$ & 0.059 \\
\hline \multirow[t]{3}{*}{ Urban } & 3.49 & $<0.001$ & 9.36 & $<0.001$ & 0.04 & $<0.001$ & 2.03 & 0.002 & 5.66 & $<0.001$ & 0.02 & 0.010 \\
\hline & \multicolumn{2}{|c|}{ High BMI } & \multicolumn{2}{|c|}{ High WC } & \multicolumn{2}{|c|}{ High WHtR } & \multicolumn{2}{|c|}{ High BMI } & \multicolumn{2}{|c|}{ High WC } & \multicolumn{2}{|c|}{ High WHtR } \\
\hline & $\begin{array}{l}\text { Odds } \\
\text { Ratio }\end{array}$ & $p$ & $\begin{array}{l}\text { Odds } \\
\text { Ratio }\end{array}$ & $p$ & $\begin{array}{l}\text { Odds } \\
\text { Ratio }\end{array}$ & $p$ & $\begin{array}{l}\text { Odds } \\
\text { Ratio }\end{array}$ & $p$ & $\begin{array}{l}\text { Odds } \\
\text { Ratio }\end{array}$ & $p$ & $\begin{array}{l}\text { Odds } \\
\text { Ratio }\end{array}$ & $p$ \\
\hline \multicolumn{13}{|l|}{ FTO rs9939609 } \\
\hline AA & 1.02 & 0.948 & 1.11 & 0.73 & 1.08 & 0.795 & 2.83 & 0.003 & 1.61 & 0.185 & 1.22 & 0.586 \\
\hline Age (years) & 0.99 & 0.359 & 1.00 & 0.991 & 0.99 & 0.388 & 1.00 & 0.871 & 1.01 & 0.26 & 1.01 & 0.204 \\
\hline Urban & 4.43 & $<0.001$ & 3.41 & $<0.001$ & 3.62 & $<0.001$ & 2.03 & 0.016 & 2.25 & 0.002 & 2.46 & 0.001 \\
\hline \multicolumn{13}{|l|}{ FTO rs1421085 } \\
\hline $\mathrm{CC}$ & 0.90 & 0.716 & 1.32 & 0.343 & 1.53 & 0.175 & 3.36 & 0.001 & 1.85 & 0.085 & 1.41 & 0.344 \\
\hline Age (years) & 0.99 & 0.361 & 1.00 & 0.958 & 0.99 & 0.359 & 1.00 & 0.850 & 1.01 & 0.270 & 1.01 & 0.214 \\
\hline Urban & 4.45 & $<0.001$ & 3.42 & $<0.001$ & 3.63 & $<0.001$ & 2.22 & 0.008 & 2.33 & 0.002 & 2.49 & 0.001 \\
\hline
\end{tabular}

2 *Recessive model. Statistical analysis was done using logistic regression model while adjusting for age and population (urban/rural).

3 The model used for linear regression: outcome $\sim$ SNPs + age + population. BMI: body mass index, WC: waist circumference, WHtR:

4 waist to height ratio. High BMI: BMI $\geq 25$; High WC: male's WC $\geq 90 \mathrm{~cm}$ and female's WC $\geq 80 \mathrm{~cm}$; High WHtR: WHtR $\geq 0.5$. The

5 significant $p$-values after Bonferroni correction are indicated in bold $(p<0.025)$. 


\section{Table 4 (on next page)}

Associations of FTO SNPs with obesity in urban vs. rural*

*Recessive model. Statistical analysis was done using logistic regression model while adjusting for age and gender (male/female). The model used for linear regression: outcome SNPs + age + gender. BMI: body mass index, WC: waist circumference, WHtR: waist to height ratio. High BMI: BMI $\geq 25$; High WC: male's $W C \geq 90 \mathrm{~cm}$ and female's $W C \geq 80 \mathrm{~cm}$; High WHtR: WHtR $\geq 0.5$. The significant $p$-values after Bonferroni correction are indicated in bold $(p<0.025)$. 
Table 4. Associations of FTO SNPs with obesity in urban vs. rural*

\begin{tabular}{|c|c|c|c|c|c|c|c|c|c|c|c|c|}
\hline & \multicolumn{6}{|c|}{ Urban $(n=318)$} & \multicolumn{6}{|c|}{ Rural $(n=294)$} \\
\hline & \multicolumn{2}{|c|}{ BMI } & \multicolumn{2}{|c|}{ WC } & \multicolumn{2}{|c|}{ WHtR } & \multicolumn{2}{|c|}{ BMI } & \multicolumn{2}{|c|}{$\mathbf{W C}$} & \multicolumn{2}{|c|}{ WHtR } \\
\hline & Estimates & $p$ & Estimates & $p$ & Estimates & $p$ & Estimates & $p$ & Estimates & $p$ & Estimates & $p$ \\
\hline \multicolumn{13}{|c|}{ FTO rs9939609 } \\
\hline $\mathrm{AA}$ & 1.09 & 0.097 & 3.04 & 0.038 & 0.02 & 0.088 & 1.53 & 0.043 & -0.59 & 0.743 & $<0.01$ & 0.694 \\
\hline Age (years) & 0.03 & 0.192 & 0.14 & 0.003 & $<0.01$ & $<0.001$ & -0.04 & 0.012 & -0.09 & 0.026 & $<0.01$ & 0.518 \\
\hline Male & 1.28 & 0.021 & 6.22 & $<0.001$ & $<0.01$ & 0.978 & -0.04 & 0.932 & 2.94 & 0.018 & -0.02 & 0.044 \\
\hline \multicolumn{13}{|c|}{ FTO rs1421085 } \\
\hline $\mathrm{CC}$ & 0.63 & 0.361 & 2.03 & 0.189 & 0.01 & 0.326 & 1.65 & 0.016 & 1.68 & 0.304 & 0.01 & 0.286 \\
\hline Age (years) & 0.03 & 0.213 & 0.14 & 0.004 & $<0.01$ & $<0.001$ & -0.04 & 0.010 & -0.09 & 0.020 & $<0.01$ & 0.460 \\
\hline \multirow[t]{3}{*}{ Male } & 1.32 & 0.018 & 6.29 & $<0.001$ & $<0.01$ & 0.974 & -0.05 & 0.915 & 2.87 & 0.021 & -0.02 & 0.037 \\
\hline & \multicolumn{2}{|c|}{ High BMI } & \multicolumn{2}{|c|}{ High WC } & \multicolumn{2}{|c|}{ High WHtR } & \multicolumn{2}{|c|}{ High BMI } & \multicolumn{2}{|c|}{ High WC } & \multicolumn{2}{|c|}{ High WHtR } \\
\hline & $\begin{array}{l}\text { Odds } \\
\text { Ratio }\end{array}$ & $p$ & $\begin{array}{l}\text { Odds } \\
\text { Ratio }\end{array}$ & $p$ & $\begin{array}{l}\text { Odds } \\
\text { Ratio }\end{array}$ & $p$ & $\begin{array}{l}\text { Odds } \\
\text { Ratio }\end{array}$ & $p$ & $\begin{array}{l}\text { Odds } \\
\text { Ratio }\end{array}$ & $p$ & $\begin{array}{l}\text { Odds } \\
\text { Ratio }\end{array}$ & $p$ \\
\hline \multicolumn{13}{|c|}{ FTO rs9939609 } \\
\hline $\mathrm{AA}$ & 1.36 & 0.285 & 1.71 & 0.075 & 1.69 & 0.141 & 2.10 & 0.044 & 0.92 & 0.828 & 0.84 & 0.625 \\
\hline Age (years) & 1.01 & 0.585 & 1.03 & 0.008 & 1.04 & 0.001 & 0.99 & 0.160 & 0.99 & 0.291 & 0.98 & 0.042 \\
\hline Male & 2.17 & 0.001 & 0.55 & 0.017 & 0.91 & 0.726 & 1.02 & 0.936 & 0.41 & $<0.001$ & 0.72 & 0.168 \\
\hline \multicolumn{13}{|c|}{ FTO rs1421085 } \\
\hline $\mathrm{CC}$ & 1.19 & 0.567 & 1.95 & 0.037 & 1.75 & 0.143 & 2.25 & 0.016 & 1.20 & 0.585 & 1.38 & 0.304 \\
\hline Age (years) & 1.00 & 0.610 & 1.03 & 0.010 & 1.04 & 0.001 & 0.99 & 0.140 & 0.99 & 0.269 & 0.98 & 0.034 \\
\hline Male & 2.19 & 0.001 & 0.54 & 0.015 & 0.91 & 0.733 & 1.02 & 0.951 & 0.41 & $<0.001$ & 0.71 & 0.148 \\
\hline
\end{tabular}

*Recessive model. Statistical analysis was done using logistic regression model while adjusting for age and gender (male/female). The model used for linear regression: outcome $\sim$ SNPs + age + gender. BMI: body mass index, WC: waist circumference, WHtR: waist to height ratio. High BMI: BMI $\geq 25$; High WC: male's WC $\geq 90 \mathrm{~cm}$ and female's WC $\geq 80 \mathrm{~cm}$; High WHtR: WHtR $\geq 0.5$. The significant $p$-values after Bonferroni correction are indicated in bold $(p<0.025)$. 